\title{
PELAKSANAAN PUTUSAN PERCERAIAN ATAS NAFKAH ISTRI DAN ANAK DI PENGADILAN AGAMA
}

\author{
Ahmad Nur Faizin \\ Program Magister Ilmu Hukum \\ Pascasarjana Fakultas Hukum Universitas Islam Malang \\ Jalan Mayjen Haryono No. 139 Malang
}

\begin{abstract}
Abstrak
Dalam putusan mengenai pelaksanaan nafkah iddah, mut'ah serta nafkah untuk anak, eksekusi riil dilaksanakan oleh para pihak secara sukarela, atau oleh pengadilan melalui juru sita pengadilan setelah ada permohonan apabila salah satu pihak tidak bersedia melaksanakan putusan tersebut secara sukarela. Pengadilan tidak akan melaksanakan eksekusi apabila tidak ada permohonan eksekusi dari yang dirugikan. Untuk itu apabila permohonan eksekusi dilakukan maka terlebih dahulu mantan suami akan diberikan teguran agar memenuhi kewajibannya atas putusan pengadilan yang berkaitan dengan pemberian nafkah.

Kata kunci: nafkah, perceraian, perkawinan, putusan pengadilan
\end{abstract}

\section{Abstract}

In the decision regarding the implementation of the iddah, mut'ah and maintenance for the child, the real execution is either voluntary, or by the court through the court's arbitrator upon application if either party is not willing to execute the decision voluntarily. The court will not execute the execution if there is no application for the execution of the damages. Therefore, if the execution of the application is made then the ex-husband will be reprimanded for fulfilling his duty on the court's decision relating to the provision of maintenance.

Keywords: alimony, divorce, marriage, court decision

\section{PENDAHULUAN}

Di antara sekian masalah yang menyangkut hubungan antar manusia atau dalam perspektif Agama Islam dikenal dengan istilah muamalat duniawiyat, masalah perkawinan (munakahat) dengan segala persoalan yang berada di sekitarnya mendapatkan perhatiannya yang istimewan Perkawinan merupakan peristiwa penting dalam kehidupan setiap manusia. Perkawinan yang terjadi antara seorang pria dengan seorang wanita akan menimbulkan akibat lahir maupun batin antara mereka, terhadap masyarakat dan juga hubungannya dengan harta kekayaan yang diperoleh di antara mereka baik sebelum dan selama perkawinan ${ }^{1}$.

Perkawinan merupakan suatu perjanjian yang mengikat lahir batin dengan dasar iman. Hidup bersama merupakan suatu fenomena yang merupakan kodrat bagi setiap manusia, dan mengingat manusia merupakan mahluk sosial, sehingga hanya manusia-manusia yang memiliki kelainan-kelainan sajalah yang mampu hidup mengasingkan diri dari orang-orang lainnya. Dalam bentuknya yang

\footnotetext{
${ }^{1}$ Musthafa Kamal dkk, Fikh Islam, (Yogyakarta: Citra Karsa Mandiri, 2002), hal. 243
} 
terkecil, hidup bersama itu dimulai dengan adanya keluarga. Lembaga perkawinan merupakan dasar peradaban umat manusia dan tempat bagi manusia untuk mengabadikan diri satu sama lain dan saling menghormati perasaan ${ }^{2}$. UndangUndang No. 1 Tahun 1974 tentang Perkawinan, merupakan unifikasi dalam bidang hukum perkawinan bagi seluruh warga negara Indonesia. Undang-Undang Perkawinan tersebut diundangkan pada tangal 2 Januari 1974 dan mulai berlaku secara efektif pada tanggal 1 Oktober 1975 bersamaan dengan saat berlakunya Peraturan Pelaksanaannya yakni PP No. 9 Tahun 1975 tentang Pelaksanaan Undang-Undang No. 1 Tahun 1974.

Dengan demikian terhadap perkawinan dan hal-hal yang berkaitan dengan perkawinan apabila terjadi sebelum 1 Oktober 1975, digunakan ketentuanketentuan atau peraturan-peraturan lama. Sebagaimana diketahui, sebelum Undang-Undang Perkawinan belum efektif, di Indonesia terdapat beraneka ketentuan yang mengatur tentang perkawinan di antaranya adalah Hukum Islam, Hukum Adat, Kitab Undang-Undang Hukum Perdata (KUH Perdata), Peraturan perkawinan Bagi Golongan Indonesia Kristen (HOCI), Peraturan Perkawinan Campuran (Reglemennt Gemengde Huwelijken/RGH). Sedangkan jika perkawinan dan hal yang berkaitan dengan perkawinan itu dilakukan setelah 1 Oktober 1975, maka dasar yang digunakan adalah ketentuan Undang-Undang Perkawinan.

Dengan demikian terhadap perkawinan dan hal-hal yang berkaitan dengan perkawinan apabila terjadi sebelum 1 Oktober 1975, digunakan ketentuanketentuan atau peraturan-peraturan lama. Sebagaimana diketahui, sebelum Undang-Undang Perkawinan belum efektif, di Indonesia terdapat beraneka ketentuan yang mengatur tentang perkawinan di antaranya adalah Hukum Islam, Hukum Adat, Kitab Undang-Undang Hukum Perdata (KUH Perdata), Peraturan perkawinan Bagi Golongan Indonesia Kristen (HOCI), Peraturan Perkawinan Campuran (Reglemennt Gemengde Huwelijken/RGH). Sedangkan jika perkawinan dan hal yang berkaitan dengan perkawinan itu dilakukan setelah 1 Oktober 1975, maka dasar yang digunakan adalah ketentuan Undang-Undang Perkawinan.

Pasal 1 Undang-Undang Nomor 1 Tahun 1974 tentang Perkawinan merumuskan pengertian perkawinan sebagai berikut: Perkawinan adalah ikatan lahir batin antara seorang pria dengan seorang wanita sebagai suami istri dengan tujuan membentuk keluarga (rumah tangga) yang bahagia dan kekal berdasarkan Ketuhanan Yang Maha Esa. Pasal 2 ayat (1) Undang-Undang Nomor 1 Tahun 1974 tentang sedangkan sahnya perkawinan yang berbunyi Perkawinan adalah sah apabila dilakukan menurut hukum masing-masing agamanya dan kepercayaannya itu. Setiap pasangan suami istri mendambakan keharmonisan berumah tangga, sebagaimana tujuan dari suatu perkawinan yang telah disebutkan di atas. Prinsip perkawinan sendiri adalah untuk membentuk suatu keluarga atau rumah tangga yang tentram, damai dan kekal untuk selama-lamanya, namun perjalanan kehidupan tidak selalu sesuai dengan keinginan manusia. Percerian dapat terjadi oleh berbagai faktor dalam suatu perkawinan. Perceraian merupakan

\footnotetext{
${ }^{2}$ Lili Rasjidi, Hukum Perkawinan dan Perceraian di Malaysia dan di Indonesia. (Bandung: PT. Remaja Rosdakarya. 1991). hal. 1
} 
realitas yang tidak dapat dihindari apabila kedua belah pihak telah mencoba untuk mencari penyelesaian dengan jalan damai yakni dengan jalan musyawarah, jika masih belum terdapat kesepakatan dan merasa tidak bisa melanjutkan keutuhan keluarga maka barulah kedua belah pihak bisa membawa permasalahan ini ke pengadilan untuk dicari jalan keluar yang terbaik. Pengadilan merupakan upaya terakhir untuk mempersatukan kembali suami dan istri yang berniat bercerai tadi dengan jalan membuka lagi pintu perdamaian dengan cara musyawarah memakai penengah yakni hakim, untuk orang yang beragama Islam akan membawa permasalahan ini kepada Pengadilan Agama sementara untuk agama lainnya merujuk kepada Pengadilan Negeri tempat mereka tinggal. Secara umum alasan perceraian dalam masyarakat adalah sudah tidak ada lagi kecocokan di antara suami dan istri yang disebabkan oleh berbagai hal. Perceraian merupakan suatu perbuatan hukum yang tentunya akan membawa pula akibat-akibat hukum tertentu. Sesuai dengan ketentuan Pasal 144 Kompilasi Hukum Islam (KHI), perceraian dapat terjadi karena adanya talak dari suami atau gugatan perceraian yang dilakukan oleh istri, perceraian tersebut hanya dapat dilakukan atas dasar putusan hakim di depan sidang Pengadilan Agama (Pasal $115 \mathrm{KHI}$ ).

Perceraian yang terjadi karena adanya talak dari suami terhadap istrinya, maka sesuai dengan ketentuan Pasal 41 (c) Undang-Undang Nomor 1 Tahun 1974, pengadilan dapat mewajibkan kepada mantan suami untuk memberikan biaya penghidupan dan atau menentukan sesuatu kewajiban kepada mantan istrinya. Pasal ini menetukan kewajiban dari mantan suami yang berupa mut'ah, nafkah iddah (bila istrinya tidak nusyus) dan nafkah untuk anak-anak. Dalam hal ini walaupun tidak adanya suatu tuntutan dari istri majelis hakim dapat menghukum mantan suami membayar kepada mantan istri berupa mut'ah, nafkah iddah dan nafkah anak. Atas dasar latar belakang tersebut penulis mengambil judul "Pelaksanaan Putusan Perceraian atas Nafkah Istri dan Anak dalam Praktek di Pengadilan Agama Banyuwangi.

\section{METODE PENELITIAN}

Penelitian adalah usaha secara ilmiah untuk mengetahui atau mempelajari fakta-fakta yang baru dapat diartikan sebagai penyaluran rasa ingin tahu. Penelitian pada dasarnya adalah suatu kegiatan terencana dilakukan dengan metode ilmiah bertujuan untuk mendapatkan data baru guna membuktikan kebenaran atau ketidakbenaran dari suatu gejala atau hipotesa yang ada $^{3}$.

Penelitian hukum merupakan suatu kegiatan ilmiah yang didasarkan pada metode, sistematika dan pemikiran tertentu yang bertujuan untuk mempelajari satu atau beberapa gejala hukum tertentu dengan jalan menganalisanya. Kecuali itu maka juga diadakan pemeriksaan mendalam terhadap fakta hukum tersebut untuk kemudian mengusahakan suatu pemecahan atas permasalahanpermasalahan yang timbul di dalam gejala-gejala yang bersangkutan. ${ }^{4}$

Jenis penelitian yang digunakan dalam penelitian ini adalah penelitian yuridis sosiologis yaitu penelitian dibidang hukum yang meneliti, mengkaji dan membahas suatu masalah dari aspek gejala sosialnya di dalam lingkup hukum

\footnotetext{
3. Bambang Waluyo, Penelitian Hukum Dalarn Praktek, (JakartaL Sinar Grafika, 1991), hal. 2

4 Soerjono Soekanto, Pengantar Penelitian Hukum, Cetakan 2, (Jakarta: Penerbit Universitas Indonesia, 1986)
} 
yang ada kaitannya dengan kenyataan yang terjadi didalam praktek. Jadi yang dikaji prilaku-prilaku masyarakat dalam bidang hukum, dengan kata lain yang menjadi lingkup pembahasannya adalah pelaksanaan hukum di masyarakat.

Data yang diperoleh langsung dari hasil penelitian dilapangan

(field research) melalui para responden. Teknik pengumpulan data dilakukan dengan wawancara, dokumentasi dan observasi.

Dari data yang diperoleh berdasarkan penelitian lapangan maupun penelitian kepustakaan kemudian yang penulis lakukan adalah mengolah data. Selanjutnya data tersebut penulis analisis dengan menggunakan metode analisis diskriptif kualitatif, yaitu mengambarkan secara jelas atas fenomena yang terjadi dimasyarakat yang kemudian secara diskriptif yaitu menyusun data yang penulis kumpulkan secara sistimatis, sehingga akan menghasilkan sesuai dengan pembahasan yang dikemukakan.

\section{PEMBAHASAN}

Pada dasarnya setiap orang yang melaksanakan perkawinan mempunyai tujuan atau cita-cita untuk selama-lamanya. Tetapi adakalanya suatu perkawinan karena sebab-sebab tertentu dapat berakibat putus atau tidak dapat dilanjutkan lagi, dan pada akhirnya perkawinan tersebut harus berakhir dengan perceraian antara suami istri.

Undang-Undang Nomor 1 Tahun 1974 tentang Perkawinan menyebut secara umum mengenai putusnya hubungan perkawinan dalam tiga golongan seperti yang tercantum dalam Pasal 38 Undang-Undang Nomor 1 Tahun 1974 tentang Perkawinan sebagai berikut.

a. Kematian Putusnya perkawinan sebab kematian adalah dengan meninggalnya salah salah satu pihak (suami atau istri). Sejak saat meninggalnya salah satu pihak itulah perkawinan itu menjadi putus

b. Perceraian Putusnya perkawinan karena perceraian adalah dengan pernyataan talak dari seorang suami.

c. Atas keputusan pengadilan.

Putusnya perkawinan atas putusan pengadilan adalah putusnya perkawinan karena gugatan istri. Gugatan seorang istri yang melangsungkan perkawinan menurut agama Islam diajukan ke Pengadilan Agama, sedangkan gugatan seorang suami/istri yang melangsungkan perkawinan menurut agama dan kepercayaan bukan Islam gugatan diajukan ke Pengadilan Negeri.

Dalam Undang-Undang Nomor 1 Tahun 1974 tentang Perkawinan, dicantumkanlah suatu asas bahwa tujuan perkawinan adalah untuk membentuk keluarga bahagia, kekal dan sejahtera, dengan demikian perceraian bukanlah suatu hal yang mudah untuk dilakukan menurut undang-undang ini. Untuk melakukan perceraian harus ada cukup alasan, bahwa antara suami istri itu tidak akan dapat hidup rukun sebagai suami istri. Perceraian hanya mungkin dengan salah satu alasan seperti disebutkan dalam Undang-Undang Perkawinan dan Peraturan Pelaksanaannya, yang harus dilakukan di depan Pengadilan. Bagi warga negara yang beragama Islam perceraian dilakukan di depan Pengadilan Agama.

Suatu perceraian secara hukum hanya dapat dilakukan di pengadilan karena pengadilan merupakan forum hukum yang dapat memberikan keputusan bagi para pihak terkait. Mengenai tata cara Perceraian, peraturan perundang- 
undangan yang berlaku di Indonesia membagi dua klasifikasi cara berdasarkan agama atau kepercayaan yang dipeluk oleh pemohon Perceraian yaitu:

1. Tata cara perceraian bagi mereka yang melangsungkan perkawinan yang beragama Islam berdasarkan Pasal 14 sampai dengan Pasal 18 Peraturan Pemerintah Nomor 9 Tahun 1975 tentang Pelaksanaan Undang-Undang Nomor 1 Tahun 1974 tentang Perkawinan, serta Pasal 28 dan 29 Peraturan Menteri Agama Republik Indonesia Nomor 3 Tahun 1975. Pada kedua peraturan tersebut pada pokoknya adalah sebagai berikut:

a. Gugatan perceraian yang diajukan oleh suami atau istri diajukan kepada pengadilan yang daerah hukumnya meliputi tempat kediaman tergugat. Permohonan ini harus dilengkapi dengan alasan-alasannya dan, meminta untuk diadakan sidang keperluan tersebut. Pengadilan Agama akan mempelajari isi surat permohonan dan dalam waktu selambat-lambatnya tiga puluh hari setelah diterimanya permohonan, pemohon akan dipanggil bersama-sama dengan istrinya untuk didengar dan diminta penjelasan tentang segala sesuatu yang berkenaan dengan maksudnya untuk bercerai.

b. Setelah menerima penjelasan, Pengadilan Agama untuk pertama kalinya berusaha mendamaikan kembali kedua belah pihak yang akan bercerai dengan meminta bantuan Badan Penasehat Perkawinan dan Penyelesaian Perceraian yang biasa dikenal dengan BP4.

c. Dalam persidangan tentunya diwarnai dengan ketegangan ketegangan dari kedua pihak yang menginginkan dilaksanakan perceraian, sehingga sidang tidak harus selesai sekali bersidang tetapi mungkin juga berkali-kali. Pada setiap kali persidangan hakim juga berusaha mendamaikan lagi, sampai pengadilan berpendapat bahwa kedua pihak tidak dapat lagi didamaikan dan sudah cukup alasan talak. Lalu diadakan lagi sidang untuk mendengarkan dan menyaksikan pengucapan talak, di mana pada saat tersebut dihadiri juga oleh istrinya atau wakilnya. Sehabis mengikrarkan talak bekas suami kemudian menandatangani surat ikrar.

d. Selanjutnya Pengadilan membuat surat keterangan tentang terjadinya talak rangkap empat untuk keperluan: lembar pertama dilampiri surat ikrar dikirimkan kepada Pegawai Pencatat Nikah setempat Lembar kedua dan ketiga masing-masing diberikan kepada suami istri sedang lembar keempat untuk arsip.

e. Perceraian terjadi pada saat pengucapan talak di depan sidang Pengadilan Agama tersebut di atas.

Apabila talak sudah terjadi, maka kutipan akta nikah yang dipegang oleh masing-masing suami dan istri dicabut dan ditahan oleh Pengadilan Agama di tempat talak itu diikrarkan dan diberi catatan pada kolom yang tersedia bahwa pemilik sudah menjatuhkan/dijatuhi talak.

2. Tata-cara bagi seorang suami atau istri yang melangsungkan perkawinan menurut agama dan kepercayaan selain Islam. Gugatan perceraian dengan 
alasan-alasan seperti yang sudah dikemukakan sebelumnya, dan diajukan baik oleh suami ataupun istri atau wakil kepada Pengadilan Negeri dengan daerah hukum yang meliputi wilayah tempat tinggal tergugat. Apabila ada hal-hal lain di luar itu, misalnya tempat tergugat tidak menentu, permohonan perceraian ditujukan kepada Pengadilan Negeri dengan wilayah hukumnya meliputi tempat tunggal si penggugat. Gugatan cerai karena ditinggal terus menerus tanpa alasan yang sah dapat diajukan pada Pengadilan Negeri dimana penggugat berdomisili, asal sudah melewati batas waktu yang diisyaratkan dalam Undang-Undang Perkawinan. Sedangkan gugatan cerai dengan alasan cekcok yang tidak ada harapan untuk rukun kembali, diajukan di Pengadilan Negeri empat kediaman tergugat.

Pemeriksaan perkara cerai talak yang diatur dalam Bab IV, Bagian Kedua, Paragraf 2 Undang-Undang No. 7 Tahun 1989, hampir sama apa yang diatur dalam Bab V Peraturan Pemerintah No. 9 Tahun 1975. Adapun mengenai pemeriksaan perceraian yang ditentukan dalam Undang-Undang terdiri dari:

1. Cerai Talak

a. Suami mempunyai jalur tertentu dalam upaya menuntut upaya perceraian yaitu jalur suami melalui cerai talak.

b. Jalur hukum untuk suami ditempuh melalui gugat permohonan baik lisan atau tertulis ke Pengadilan Agama.

c. Dalam UU No. 7 Tahun 1989 ditentukan sifat gugat cerai talak adalah berupa permohonan yang identik dengan gugat volunter, namun dia berbeda dengan dari gugat volunter yang mumi. Gugat volunter yang mumi adalah sepihak, hanya pemohon saja. Orang yang disebut dalam permohonan sebagai objek, tidak berdiri sebagai subjek. Sedangkan dalam cerai talak istri sebagai pihak dan subjek perdata, malahan mempunyai hak untuk mengajukan banding dan kasasi. Jadi disini terlihat keunikan gugat cerai talak dibanding dengan gugat volunter pada umumnya.

d. Suami sebagai pihak pemohon dan istri sebagai pihak termohon.

Permohonan cerai talak diajukan kepada Pengadilan yang daerah

hukumnya meliputi tempat kediaman termohon, kecuali apabila termohon dengan sengaja meninggalkan tempat kediaman yang ditentukan bersama tanpa ijin pemohon.

e. Dalam hal pemohon dan termohon bertempat tinggal dl luar negeri, maka permohonan diajukan kepada Pengadilan yang daerah hukumnya meliputi tempat mereka melangsungkan perkawinan

f. Pengadilan Agama dapat mengabulkan atau menolak permohonan tersebut dan terhadap keputusan tersebut dapat diminta upaya banding dan kasasi.

g. Pengadilan Agama yang bersangkutan mempelajari permohonan tersebut dalam waktu tiga puluh hari setelah itu memanggil pemohon dan termohon untuk dimintai penjelasan segala sesuatu yang berhubungan dengan maksud menjatuhkan talak.

h. Setelah Pengadilan Agama tidak berhasil menasehati atau mendamaikan kedua belah pihak dan ternyata cukup alasan untuk menjatuhkan talak serta yang bersangkutan tidak mungkin lagi hidup rukun dalam rumah tangga, Pengadilan Agama menjatuhkan keputusannya tentang ijin untuk 
mengikrarkan talak.

i. Setelah keputusan mempunyai keputusan hukum tetap, suami mengikrarkan talak di depan sidang Pengadilan Agama, dihadiri oleh istri atau kuasanya.

j. Bila suami tidak mengucapkan ikrar talak dalam waktu tempo enam bulan terhitung sejak keputusan Pengadilan Agama tentang ijin ikrar talak baginya mempunyai kekuatan hukum tetap, maka hak suami untuk diadakan mengikrarkan talak gugur dan ikatan perkawinan tetap utuh.

k. Setelah penyaksian ikrar talak, Pengadilan Agama membuat penetapan tentang terjadinya talak rangkap empat yang merupakan bukti perceraian bagi bekas suami atau istri.

1. Helai pertama beserta surat ikrar talak dikirimkan kepada Pegawai pencatat nikah yang mewilayahi tempat tinggal suami untuk diadakan pencatatan helai kedua dan ketiga masing-masing diberikan kepada suami istri dan helai keempat disimpan oleh Pengadilan Agama.

2. Cerai Gugat.

a. Jalur untuk menuntut perceraian bagi istri adalah cerai gugat, yang pada dasarnya tats cara pemeriksaan tidak banyak berbeda dengan cerai talak. Misal persamaannya tentang hat yang berkenaan dengan pengiriman salinan dan pemberian akta cerai.

b. Yang bertindak sebagai penggugat adalah istri clan di tempat lain suami sebagai tergugat.

c. Gugatan diajukan kepada Pengadilan Agama meliputi tempat kediaman penggugat.

d. Seorang istri yang mengajukan gugatan perceraian dengan jalan khuluk, menyampaikan pemohonan kepada Pengadilan Agama yang mewilayahi tempat tinggalnya disertai alasan-alasannya.

e. Dalam sidang tersebut Pengadilan Agama memberikan penjelasan tentang akibat khuluk dan memberikan nasehat-nasehatnya.

f. Setelah itu kedua belah pihak menyepakati besarnya iwald atau tebusan.

g. Jika sudah menyepakati besarnya iwald maka Pengadilan Agama memberikan penetapan tentang ijin bagi suami untuk mengikrarkan talaknya di depan sidang Pengadilan Agama.

Hukum Acara yang berlaku di pengadilan dalam perkara perceraian, secara garis besar mengikuti Hukum Acara Perdata. Namun terdapat kekhususan yang berlaku di dalam Hukum Acara di Pengadilan Agama, meliputi kewenangan relatif Pengadilan Agama, sifat persidangan, pemanggilan, pemeriksaan, pembuktian, dan biaya perkara, serta pelaksanaan putusan. Kekhususan Hukum Acara yang berlaku pada Pengadilan Agama di dasarkan pada Pasal 54 Undang-Undang Nomor 7 Tahun 1989 tentang Peradilan Agama jo Undang-Undang Nomor 3 Tahun 2006 tentang Perubahan Atas Undang-Undang Nomor 7 Tahun 1989 tentang Peradilan Agama (Undang-Undang Peradilan Agama). Dengan demikian Hukum Acara yang berlaku pada Pengadilan Agama adalah Hukum Acara Perdata yang berlaku pada Pengadilan Umum, kecuali mengenai sejumlah hal lainnnya, yang diatur khusus, meliputi: 
a. Bentuk dan proses perkara;

b. Kewenangan relatif Pengadilan Agama;

c. Pemanggilan pihak-pihak;

d. Pemeriksaan, pembuktian dan upaya damai;

e. Biaya Perkara;

f. Putusan hakim dan upaya hukum.

Selain mengacu kepada Undang-Undang Peradilan Agama, menurut penulis proses beracara di Pengadilan Agama juga mengacu pada UndangUndang Nomor 1 Tahun 1974 tentang Perkawinan jo Peraturan Pemerintah Nomor 9 Tahun 1975 tentang Pelaksanaan Undang-Undang Nomor 1 Tahun 1974 tentang Perkawinan Undang-Undang Nomor 5 Tahun 2004 tentang Mahkamah Agung. Kemudian Peraturan Menteri Agama Nomor 2 Tahun 1987 tentang Wali Hakim dan Kompilasi Hukum Islam (KHI), yang dengan Instruksi Presiden Republik Indonesia Nomor 1 Tahun 1991 jo Keputusan Menteri Agama Nomor 154 Tahun 1991. Seluruh Undang-Undang dan peraturan tersebut dapat dipergunakan dalam menyelesaikan masalah-masalah atau perkara dibidang perkawinan, kewarisan, wasiat hibah, shodaqoh berdasarkan Hukum Islam serta Kitab-kitab Fiqih Islam, sebagai sumber penemuan hukum.

Dalam perkara perceraian sesuai dengan ketentuan Pasal 114 Kompilasi Hukum Islam (KHI), perceraian dapat terjadi karena adanya talak dari suami atau gugatan perceraian yang dilakukan oleh istri, perceraian tersebut hanya dapat dilakukan atas dasar putusan hakim di depan sidang Pengadilan Agama setelah Pengadilan Agama tidak berhasil mendamaikan para pihak (Pasal $115 \mathrm{KHI}$ ).

Pada Pengadilan Agama setidaknya secara umum ada 8 kali sidang, dalam proses perceraian, yakni :

1. Sidang pembacaan gugatan/perdamaian;

2. Sidang jawaban;

3. Sidang replik;

4. Sidang duplik;

5. Sidang bukti-saksi Penggugat;

6. Sidang bukti-saksi Tergugat;

7. Sidang kesimpulan;

8. Sidang Putusan;

9. Ucap talaq (jika yang ajukan gugatan cerai adalah si suami)

Sedangkan di Pengadilan Negeri ada 10 kali pertemuan sidang yakni :

1. sidang mediasi (perdamaian) pertama;

2. sidang mediasi ke-2;

3. sidang mediasi ke-3;

4. sidang jawaban;

5. sidang replik;

6. sidang duplik;

7. sidang bukti-saksi Penggugat;

8. sidang bukti-saksi Tergugat;

9. sidang kesimpulan;

10. sidang Putusan. 
Perceraian yang terjadi karena adanya talak dari suami terhadap istrinya, maka sesuai dengan ketentuan Pasal 41 (c) Undang-Undang Nomor 1 Tahun 1974 tentang Perkawinan, pengadilan dapat mewajibkan kepada mantan suami untuk memberikan biaya penghidupan dan atau menentukan sesuatu kewajiban kepada mantan istrinya. Pasal ini menentukan kewajiban dari mantan suami yang berupa mut'ah, nafkah iddah (bila istrinya tidak nusyus) dan nafkah untuk anak-anak.

Nafkah iddah adalah pemberian nafkah dari (mantan) suami kepada (mantan) istrinya selama waktu tertentu (selama masa idah) setelah diucapkannya talak oleh si (mantan) suami. Nafkah iddah umumnya berupa uang. Sedangkan mut'ah adalah pemberian dari (mantan) suami kepada (mantan) istri sebagai akibat dari adanya perceraian, dimana istri telah dijatuhi talak. Mut'ah dapat berupa benda/perhiasan ataupun uang, umumnya besarnya biaya nafkah tersebut disesuaikan berdasarkan kesepakatan atau berdasarkan kemampuan si (mantan) suami. Mut'ah wajib diberikan oleh mantan suami dengan syarat belum ditetapkan mahar bagi istri ba'da al dukhul dan percerain atas kehendak suami.

Menurut historis iddah telah dikenal sejak zaman dahulu. Para ulama telah sepakat iddah itu hukumnya wajib bagi istri yang telah diceraikan. Iddah ialah masa tunggu atau tenggang waktu sesuai dengan jatuhnya thalak dari suami, dimana pada masa iddah ini suami boleh untuk merujuk kepada istrinya. Sehingga pada masa iddah ini si istri belum boleh untuk melangsungkan perkawinan dengan laki-laki lain.

Pada masa iddah ini sebenarnya untuk meyakinkan kekosongan rahim si istri agar terhindar dari percampuran atau kekacauan nasab bagi anak yang dikandung. Di samping itu untuk memikir kembali atau jalan yang mereka tempuh, apakah untuk merujuk kembali atau tetap meneruskan perceraian yang telah terjadi. Bagi istri yang telah diceraikan oleh suaminya, baik istri tersebut dicerai hidup dari pihak si suami atau si istri tersebut sedang mengandung atau tidak, maka si istri tersebut wajib untuk menjalani masa iddah sebagaimana tercantum dalam Kompilasi Hukum Islam Pasal 153 ayat yang menegaskan bahwa bagi seorang istri yang putus perkawinannya berlaku waktu tunggu atau iddah, kecuali qobla dukhul dan perkawinan putus bukan karena kematian suami. Iddah itu mempunyai beberapa unsur yaitu :

a. Suatu tenggang waktu tertentu

b. Wajib dijalani si bekas istri

c. Karena ditinggal mati oleh suaminya maupun diceraikan oleh suaminya

d. Keharaman untuk melakukan perkawinan selama masa iddah, untuk memperjelas pengertian tersebut di atas, bahwa iddah menurut pengertian hukum Islam ialah masa tunggu yang ditetapkan oleh hukum

Oleh karena itu, setiap istri yang diceraikan suaminya diharuskan untuk menjalani masa iddah, yang lama waktunya ditetapkan menurut keadaan istri yang diceraikan atau suami yang menceraikannya, yakni apakah perceraian itu terjadi karena cerai proses pengadilan atau cerai karena kematian. Setelah terjadinya perceraian berdasarkan hukum perdata maupun hukum syara' si suami dibebankan untuk memberikan nafkah kepada pihak mantan istri. Dan apabila si suami tidak memberikannya, nafkah kehidupan (uang belanja) maka si istri dapat mengajukan masalah tersebut kepada pengadilan agama. 
Dalam masa iddah tersebut terdapat hak dan kewajiban suami-istri, yaitu: Hak Istri pada masa iddah

a. Mendapatkan nafkah selama masa iddah

b. Mendapatkan perumahan selama masa iddah

c. Istri berhak memutuskan untuk rujuk kembali, sedangkan kewajiban istri adalah masa berkabung bila ia ditinggal mati suaminya.

Kewajiban suami pada masa iddah istri

a. Suami wajib memberikan nafkah pada istri

b. Suami wajib memberikan perumahan pada istri

c. Suami berhak untuk merujuk kembali atau tidak

Hak istri merupakan kewajiban suami untuk melaksanakan atau

memenuhi hak-hak istri. Sedangkan kewajiban istri merupakan hak suami yang harus dijalankan oleh istri pada masa iddah. Pasal 4 (sub c) Undang-Undang No. 1 Tahun 1974 menyebutkan bahwa pengadilan agama dapat

mewajibkan kepada bekas suami untuk memberikan biaya penghidupan dan atau menentukan suatu kewajiban bagi istri. Hal ini juga dipertegas dalam Kompilasi Hukum Islam Pasal 81 ayat (1 dan 2) yang menegaskan suami wajib menyediakan tempat tinggal bagi istri dan anak-anaknya atau bekas istrinya yang masih dalam iddah.

Bila terjadi perselisihan mengenai jumlah, dapat dianjurkan dan diberikan pengarahan oleh pengadilan agama untuk diselesaikan secara musyawarah dan kekeluargaan. Akan tetapi bila tidak terjadi kesepakatan dalam penentuan jumlah maka pengadilan agama dapat menentukan jumlahnya yang disesuaikan dengan kemampuan suami dan tidak memberatkannya, dan sebaliknya diberikan pada saat setelah pembacaan sighot thalak di muka majelis hakim pengadilan agama melalaikan kewajibannya, atau sebab yang lainnya yaitu istri mengikhlaskan suami untuk tidak melaksanakan kewajibannya. Hal ini sesuai dengan Pasal 80 ayat (4) dan (7) Kompilasi Hukum Islam.

\section{PENUTUP}

Pengadilan Agama dapat mewajibkan kepada bekas suami untuk memberikan biaya penghidupan dan atau menentukan suatu kewajiban bagi istri. Dalam gugatan (cerai talak) suami terhadap istri, hakim diberikan kewenangan oleh undang-undang membebani suami untuk memberikan nafkah iddah dan mut'ah terhadap istri. Gugatan balik disisi istri juga diberikan hak untuk mengajukan gugatan balik untuk nafkah anak, iddah dan mut'ah. Jika cerai gugat dari istri, disamping mengajukan gugatan perceraian sekaligus mengajukan nafkah untuk istri (diri sendiri/penggugat) dan nafkah anak. Permohonan istri atas nafkah, biaya pemeliharaan anak, dan harta perkawinan dapat juga terjadi selama proses pemeriksaan berlangsung. Pada saat pemeriksaan perkara perceraian sedang berjalan, istri sebagai penggugat dapat mengajukan permohonan kepada hakim agar selama proses pemeriksaan perkara berlangsung lebih dulu ditetapkan nafkah, biaya pemeliharaan anak, dan harta perkawinan. Jadi sebelum pokok perkara diputus, hakim menetapkan lebih dulu berapa nafkah yang harus dibayar suami kepada istri setiap bulan. Berapa tiap bulan biaya pemeliharaan anak yang wajib dipenuhi suami serta kepada siapa diserahkan penjagaan harta bersama dan 
harta pribadi istri. Putusan yang seperti ini dapat dijatuhkan hakim mendahului putusan pokok perkara, dan putusan ini mempunyai kekuatan mengikat kepada kedua belah pihak sampai putusan pokok perkara mempunyai kekuatan hukum tetap.

Buku

\section{DAFTAR PUSTAKA}

Bambang Waluyo, 1991, Penelitian Hukum Dalarn Praktek, JakartaL Sinar Grafika.

Lili Rasjidi, 1991, Hukum Perkawinan dan Perceraian di Malaysia dan di Indonesia. Bandung: PT. Remaja Rosdakarya.

Musthafa Kamal dkk, 2002, Fikh Islam, Yogyakarta: Citra Karsa Mandiri.

Soerjono Soekanto, 1986, Pengantar Penelitian Hukum, Cetakan 2, Jakarta: Penerbit Universitas Indonesia.

\section{Peraturan Perundang-Undangan}

Undang-undang RI nomor 1 tahun 1974 tentang Perkawinan dan Kompilasi Hukum Islam.

Undang-Undang Nomor 1 Tahun 1974 tentang Perkawinan

Peraturan Pemerintah Nomor 9 Tahun 1975 tentang Pelaksanaan Undang-Undang Nomor 1 Tahun 1974 tentang Perkawinan

Instruksi Presiden Nomor 1 Tahun 1991, tentang Penyebarluasan Kompilasi Hukum Islam. 